\title{
Slotter Line Device
}

National Cancer Institute

\section{Source}

National Cancer Institute. Slotter Line Device. NCI Thesaurus. Code C50179.

A device designed to make a long itudinal cut through the protective cladding of a fiber bundle without harming the fibers. 